Obviously, mythological image of gradivnyk/grindinar was formed later and it absorbed some features of black magician/solomonar. On the one hand the belief in gradivnyk/grindinar developed human mind and on the other hand put a person (not two-soul man) over the nature. Certainly, such an attitude to correlation between a person and nature can appear only in that case when the cultural self-identification of humanity happened and total fear against unknown disappeared. Nature (storm, thunder and lightning) had already realized as guided and not ruinous forces. The features of a cult were erased and person's desire to control surrounding world and all things which scared people in the past was established. Perception of black magician/solomonar and gradivnyk/grindinar was identified as an attempt of a person to find the features of deity, to show the ability to influence the nature.

Key words: archetype, gradivnyk, grindinar, mythology, solomonar, psychoanalysis, black magician.

УДК 821.521-312.9.09

M. Fedosova

\title{
RECIPE FOR SURVIVAL: HIROSHI SAKURAZAKA'S SCIENCE FICTION NOVEL «ALL YOU NEED IS KILL»
}

This paper analyses Hiroshi Sakurazaka's novel «All You Need Is Kill» to show how intrusion of fictional novelty allows science fiction to disguise the reality in order to investigate the present state of the world. It focuses on such SF conventions as the time loop and alien invasion employed by the writer to discuss environmental and social issues within the discourse of mechanization.

Key words: time loop, terraforming, ecological disruption, technology, mechanization.

DOI 10.34079/2226-3055-2019-12-20-149-157

Introduction. Science fiction (SF) is an extremely liberating mode since it allows the writers to present our deepest fears and desires, revealing what we either strive for or run from. SF conventions investigate the intrinsic human character and the living environment by inserting a plausible innovation (an unusual location, device, technology, being etc.) into the depiction of the familiar world thus altering it and creating cognitive dissonance. This fictional novelty, or novum, as Michael Svec and Mike Winiski suggest, «becomes the mechanism to challenge our preconceived notions $\langle\ldots\rangle$ and helps us resolve dissonance» [4, p. 39]. Within the context of SF, alien entities or futuristic worlds in the stories represent nothing but us and refer to a wide range of issues.

To show how SF identifies social anxieties and investigates probabilities of the future, the paper examines the light SF novel «All You Need Is Kill» (2004) by a contemporary Japanese writer Hiroshi Sakurazaka.

Review of the literature. To the best of our knowledge, the analysis of the novel is limited to short general reviews provided by readers on internet sites such as amazon.com, goodreads.com or YouTube. Most of the reviewers praised the deeply elaborated characters, strong plot line and masterly established technology as compared to a Hollywood adaptation 
of the novel - the film «Edge of Tomorrow» (2014, dir. Doug Liman). They also tended to regret that the movie excluded many important themes and reduced the role of strong female Rita Vrataski to a supporting character. As far as we know, «All You Need Is Kill» provides a fertile ground for a number of discourses and offers several topics for discussion. Therefore, the comprehensive analysis is required because readers' comments and reviews cannot substitute literary criticism.

The aim of the paper is to extend the current knowledge of the SF mode and to analyze how SF uses novum to elaborate on social, cultural and environmental issues related to technology. We base our study on the works of H. Bergson and J. Burton [1] concerning the discourse of mechanization and that of T. Volk [5] in addressing the cultural and social aspects of death.

Presentation of the main findings. It is worth noting that SF conventions have entered the mainstream culture and released the writers from obligation to explain their science in details (and the readers from deeply understanding it). Having made its characters merely users of high-tech instead of inventors or engineers, light SF tells stories rather than predicts the development of technology as we can see in hard SF. The novel «All You Need Is Kill» depicts the futuristic Earth half-destroyed by alien invaders from the constellation Cancer. The plot follows a raw Japanese recruit Keiji Kiriya who joins the UDF (United Defense Force - global armed forces established to fight extraterrestrials) to find the meaning of life but is killed in his first battle. Before dying, he manages to slay a commanding officer of the enemy troops and is caught in a time loop that forces him to repeat the last day of his life. In the middle of the story and in his 158 loop Keiji learns that Rita Vrataski - the legendary soldier and battle prodigy from the US Special Forces squad - is also aware of the time loops and teams up with her to escape the recurrence and defeat the alien invaders.

Environmental concern is nearly palpable in the novel that depicts how humanity struggle to stop extraterrestrials from turning the planet into a toxic desert. Approximately twenty years before the present events of the plot, an alien unmanned spacecraft approached Earth and jettisoned its payload «crèche machines» containing terraforming nanobots. The crèche machines that sank deep into the ocean released the nanobots that infested the local starfish species turning them into soil-eating creatures later called Mimics. The digestive apparatus of these monsters (for this is, from our point of view, the most suitable word in criticism for an entity that exceeds the definition of something natural or human) produced a substance suitable for the aliens and toxic to the earthlings: «They ate earth and shat out poison, leaving behind a lifeless wasteland» [3]. At first, these creatures were «peaceful» and did nothing but prepare the environment for colonization. After people had resisted and confronted them with weapons, these xenoformers evolved into powerful killing machines: «If a man were a thin pole standing on end, a Mimic would be a stout barrela barrel with four limbs and a tail, at any rate. Something like the bloated corpse of a drowned frog, we liked to say. $<. . .>$ A single swipe of one of its limbs can send a man flying in a thousand little pieces. Their javelins, projectiles fired from vents in their bodies, have the power of $40 \mathrm{~mm}$ shells» [3]. Aliens sent their xenoforming machines to reshape the planet in question without regard for any native life, but humanity was not willing to give up easily and united against the enemy they now called Mimics. As we can see, emergence of xenoformers resembles the condensed form of human evolution on the earth. Presumably originated in the deep space, we were carried on a celestial body to the earth, where we were born in water, left the oceans and became the species we are today. Industrialization, intensive farming and other human activities have changed climate, polluted soil and water with plastic and chemicals, caused greenhouse effect, led to extinction of many species of animals or plants and, as some scientists claim, endangered the whole life on the planet including our 
own future generations. As the aliens from the novel do, we look forward to the possibility of colonizing other planets rather than making the Earth a better place for all inhabitants.

It may be assumed, that this problem lies in what philosophers call mechanization. Broadly speaking, mechanization is a trait of people and society in general that means «the reduction of life to the status of the non-living» and instrumentalization of other humans (and other life-forms) in order to restrict the autonomy of one living being to sustain another [1, p. 32]. Mechanization, being inseparable from industrialization, may be considered a dividing line between the ancient and modern discourses of the surrounding world. According to Adam Roberts, «for modern, scientific man the phenomenal world is primarily an 'It'; for ancient - and also for primitive - man it is a 'Thou'» [2, p. 342]. These attitudes to the cosmos reveal two paradigms that are an inherent part of human nature, namely applying active force to and undergoing passive impression of the environment. However, within the discourse of mechanization, the essence of modernity goes deeper than a simple choice of altering the world around instead of observing it.

As Henri Bergson pointed out, mechanization also means perceiving the universe in discrete parts rather than comprehending it in its wholeness and continuity. It exists on different levels, including «the mechanization of time (its treatment as though equivalent to spatial extension), freedom (the erosion of the capacity to behave non-deterministically) and mind (its reduction to the status of machine)» [1, p. 33]. Such industrialized approach to life deprives it of its dynamics and creativity, and once mechanized and degraded, natural or social phenomena cannot be restored to their previous status. Here lies the threat to contemporary culture, because the very morality and integrity are challenged by domination of scientific thinking that tends to grasp things by breaking them down to the smallest detectible elements, thus reducing them to the status of non-living. Since humans consider themselves on the top of biological hierarchy, they ascribe their worth over other living creatures and ecological systems by moving them down the food chain. In spite of other species' value or significance on the earth, humans still consider them inferior. Selfproclaimed superiority equips people with the right to transform the planet in order to meet their contemporary needs regardless of the consequences for the future.

In the analyzed Sakurazaka's novel, we face a situation when the alien mechanized society tormented by overpopulation and lack of resources advances to a degree that it is able to transfer its technologies through space to find another planet suitable for settling. Of course, we agree that every life form needs energy and nutrition to survive as well as territory to live and multiply unless this territory already belongs to someone else. Aliens are ruthless conquerors and, upon closer examination, their society is very similar to our own: «To expand their territory, they had never shied away from sacrificing lesser life in the past. Forests had been cleared, swamps drained, dams built. There had been countless examples of people destroying habitats and driving species to extinction for their own benefit. If they could do this on their own planet, why should some unknown world in the void of space be treated differently?» [3]. As we can see, the title «All you need is kill» seems to embody a philosophy of industrialized utilitarian society and the novel itself foreshadows the global ecological disruption caused by uncontrollable planetary change. Measures taken to ensure comfortable habitation of the dominant species may be short-term because preservation of natural resources becomes crucial in the long term. In this context, an issue of morality becomes apparent. In the discussed mechanized societies, justice does not extend to the life forms considered inferior; consequently they are deprived of the right of autonomous existence and are reduced to the status of the means.

Morality emerges from freedom when not only a person has a possibility to choose what means to employ but also several means are available for selection. According 
to S. D. Alinsky, moral questions of what means to use arise if these means are equally effective. However, «if one lacks the luxury of a choice and is possessed of only one means, then the ethical question will never arise; automatically the lone means becomes endowed with a moral spirit» [4, p. 125-126]. In this context, the novel's title bears another symbolic meaning, condensing the idea that survival inevitably involves a necessity to destroy the other. This does not imply that killing is morally justified but rather it is allowed as a means of protection.

Bergson pointed out that intellect's failure to understand how life affects the society leads humans as a species to self-destruction. In his attempt to understand the human mind, Bergson developed a theory of intellect-intuition dualism that determines «two main lines» of animal evolution: «along one line, epitomized by hymenopteran species such as bees and ants, instinct is emphasized; the other line, in which humanity emerges, has tended to emphasize intellect» [1, p. 36]. Species and societies driven by intuition tend to regard life as continuity and creativity devoting their individual lives to the community alone. The intellect-driven entities, in contrast, incline towards discontinuity and materiality; their own intelligence generally threats their social collaboration and complicates their struggle to survive «through individualistic self-interest leading to antagonism, violence and abuse, or through the depression and resignation that could be expected to accompany a sense of mortality and the ultimate futility of all one's endeavours» [1, p. 39]. The discourse of mechanization significantly alters the way of determining the worth of human beings on the social scale. This may be of great concern regarding the troublesome allocation of privileges and distribution of power among different groups in society throughout the history. In the novel, bureaucracy and materialistic thinking appear to be the primary reasons why it is so difficult for humanity to defeat the Mimics: "If you really want to fight the Mimics you need helicopters or tanks. But helicopters cost money, and it takes money to train the pilots too. <...> But Japan is crawling with people. So they wrap 'em in Jackets and ship 'em to the front lines. Lemons into lemonade» [3]. The novel expresses concern about the society's inability to prioritize human life (and life in general) over things even in the face of imminent danger to the entire planet. Apparently, it explores a conception of life in relation to the non-living thus becoming an inquiry into the origins of human morality and the ways to overcome total mechanization.

On the interpersonal level, as Tyler Volk theoretically speculates, death can be used as «a motivator in our unconscious» to create a more just, tolerant and desirable society: «[T] he tolerant can be more tolerant when faced with the awareness of death. The bigoted become more bigoted. It's a choice we need to think about. $<\ldots>$ What worldview is drawn from to defend against the anxiety of death awareness matters for the future of global society» [5, p. 119]. As we can see, death does not create any new features of character; it just reinforces the existing ones and draws people to confront the depth of their nature. In the novel, Keiji shows his endurance and determination in the face of the first death with subsequent deaths only strengthening him. From the beginning, we know that he is terrified on the battlefield, but we also see the extremity of the fight and understand that he could become a brave soldier and a rather capable leader if provided with suitable training and experience. He quickly transforms from merely a survivor into an action hero when he decides to kill at least one enemy before dying. The time loop becomes a handy tool for the process of Keiji's maturing because it deprives him of the finality of death that no one can experience in reality.

Evolution of culture allows people to buffer the notion of death, but it cannot deprive them from their primordial instinct for self-preservation. Simple suppression of fear and denial of death do not provide a healthy and acceptable solution. Volk presents evidence 
that being human means to acknowledge the primal clash between the need for life and the knowledge of eventual death: «Our response to this primal clash causes us to construct and thus inhabit a psychological world that is necessarily life on a larger scale, because it must encompass both the need for life and the knowledge of death» [5, p. 124]. Hence, a person who stops fighting and fearing the inevitable may spend more time and effort on things that do matter in life. In the novel, repetitive drills and battles forge Keiji into a hard-boiled fighter while almost similar events of the daily routine give him extra time to notice smaller strokes on the bigger picture, thus allowing him to engage unconsciously in life around and establish emotional bond with the others (even though they are not aware of this). As Keiji confesses during one of the battles, «I etched the faces of the men I'd let die deep in my mind. In a few hours their pain would be gone, but I would remember. Like a thorn in my heart it tormented me, toughened me for the next battle» [3]. The protagonist's feelings of personal responsibility and self-esteem grow as he repetitively balances on the edge between life and death and become a force that pushes him forward through the loops. Keeping abovementioned theory in mind, we may conclude, that time loop in the novel functions at two levels. At the external level, Keiji has to fight the mimics and save as many of his fellow soldiers as he can. Day after day, he goes into training, improves his skills and programs his brain for the battle. Almost all time in the world is available for him, yet he barely allows himself to waste a minute on anything unimportant, that will vanish in the next loop. He tries hard to win the battle because he believes it will give him an opportunity to «wake up in a world with a tomorrow» [3]. At the internal level, the novel illustrates Keiji's efforts to manage his fear and gain self-respect. From this perspective, subjective time in the novel is always linear since the protagonist remembers his experience from the past loops, despite returning to the previous physical condition.

One's own death, as philosophers say, enables to embrace the totality of life in an instant before it vanishes. Death of another, on the contrary, enlarges life of the living ones by dissolving into them and creating «the extended self», which is «not just the dead in me but the dead in many of us, which thereby connects us to a body with various harmonics of extension» [5, p. 130]. Tyler Volk calls this a «psychological web». He says that people share parts of their selves and these parts can live in others as long as they remember them and stick to their ideas, values, beliefs, goals and knowledge. The deceased continue to exist within the living because «... we are not the individuals we think. Rather, we are composites of people we know and love» [5, p. 128]. Death of another becomes an indicator of the person's importance: «Until their death we are not aware of the full extent to which people affect us» [5, p. 130]. Since death evokes strong emotional and behavior reactions in individuals, Volk suggests that terror management may turn our awareness of death into a powerful stimulus for improving the society.

Protagonist's journey to maturity ends with realization that his life is indeed important for the humanity but this conclusion comes with a terrible prize. Keiji is able to break the loop only after he loses Rita, the girl he loves and the only person he wants to protect. The final test imposed on the character comes in a form of a duel between the two most gifted veterans of the war - Keiji Kiriya and Rita Vrataski. Since the circumstances permit only one of them to live on, Rita offers to let their skills decide their worth. Despite being a prodigy in fighting Mimics, Rita has learned everything by herself. Keiji, on the contrary, learned by watching her fighting. This fact gives him advantage over her, but only his decision to proceed determines the outcome. It should be noted, that earlier in the novel Keiji recalls a childhood game he played with other kids in which he pretended to be a hero who died to inspire his fellow soldiers to defeat the Mimics. After his encounter with death on the battlefield Keiji, however, refuses to die at any cost and his decision determines the consequent events. 
At the end, he finally acknowledges the worth not of his life, but of his experience and knowledge that would vanish in case of his death: «But if I give up now, everything would be gone. 〈...> The 159 battles that didn't exist anywhere but in my head would be gone forever, meaningless. If I gave it all I had and lost, that was one thing. But I wasn't going to die without a fight» [3]. The ability to endure may be read as the last lesson taught by Rita. As we can see, her death enlarges Keiji's worldview and provides meaning and insight to him. $\mathrm{He}$ stops pursuing a simple continuation of life and adheres to her believes and values, thus allowing her to live on within his self: "While I live and breathe, humanity will never fall. I promise you. It may take a dozen years, but I will win this war for you. Even if you won't be here to see it» [3]. By death, Rita Vrataski secures her symbolic position of the savior of humanity. In life, a sight of her crimson Jacket slaughtering the Mimics on the frontline enhanced the spirit of the fatigued soldiers. After finding a worthy replacement, she passes her duties to Keiji. She makes him realize that the essence of being human lies not in just killing the enemy but in doing the right thing and fighting for the Earth with everything good and bad on it even if he is the only one to appreciate it.

The alien xenoforming mission may be seen as an embodiment of contemporary anxiety about the advancement of warfare. The Mimics represent the culmination of scientific development of highly efficient weaponry: they are able to acquire supplies from the enemy's territory; they are chip and disposable; they are controlled remotely by software that releases the operator from necessity to be present on-site; and they can send pacifying dreams to the humans instilling the idea of surrender. Despite being produced by advanced science, the uncomplicated or even primitive structure and functions of the Mimics make them extremely murderous. After all, the Mimics do not seem to possess autonomous selves because the alien civilization made them merely hybrid devices intended for xenoforming the target environment and eliminating any native inhabitants once considered dominating: «And they didn't hold back just because a man was unarmed. They rolled right through you like a rototiller through a gopher mound» [3]. The artificial life-forms created on the basis of the starfish-nanobots symbiosis by advanced bioengineering seem to represent a fantasy of forcing the world to succumb to human needs by means of science. The pinnacle of this journey towards domination is embodied in the conquest of time. In order to secure the success of their mission the aliens are able to abort the linear time line of the battle. In case of their defeat the crèche machines create a thirty-hour time loop that takes their xenoforming troops back to the initial position and restart the battle: «The danger appeared in the memory of the Mimics as a portent, a window into the future. The Mimics that received this vision could modify their actions to safely navigate the pending danger. This $\langle\ldots\rangle$ served as a warning system to prevent some freak accident from upsetting a xenoforming plan that had taken so long to place in motion» [3]. Nevertheless, technological superiority results in what may be called perceptional myopia, or simply arrogance, meaning that scientific progress causes unbalanced understanding of the cosmos. The alien civilization, described in the novel, rely on their intellect to the extent that they disregard continuity of phenomena that can be perceived only by intuition. This highlights that mechanization in the alien society reaches its peak when the people from the distant star arrogate a foreign planet to themselves and come to claim it. However, what distances them from naturalness leads to their downfall. Humans, or indigenous life, unworthy of being taken into consideration by superior species, found out the secret of the time loop and turned the hostile technology to their advantage: "People could adapt themselves to their environment and their experiences in any number of ways. An enemy that could look into the future and perceive danger fell victim to its own evolutionary atrophy. We learned faster than they could» [3]. Unable to fight superior intellect humans appealed to their nature, namely their intrinsic potential granted by evolution 
and skills acquired by experience. What seems evident is that the writer considers intuition linked to unconsciousness more authentic as compared to intellect or intelligence that tend to be ascribed to consciousness. As Keiji progresses in his battle drills, he learns to switch off his thoughts and emotions and relies on his body's ability to receive and process information: «My body reacted before I had time to think. On the battlefield, I left my conscious mind out of the business of running my body. The cool, impartial calculations of my subliminal operating system were far more precise than I could ever be» [3]. It is not coincidental that the notion of identity shifts when the efficient soldier is compared to a machine. Blurred distinction between natural and scientifically enhanced beings shows how humanity changes under the influence of technology. Progress appears to be a reciprocal process and people both work upon it and yield to it. Of course, the novel also links the transformation of a human into a machine to the repetition within the time loop. As Keiji Kiriya analyses the iteration of the battles, he undergoes changes in his self: "I'd become a veteran who bent the war to my will. I bore the burden of endless battle like the killing machine I'd become - a machine with blood and nerves in place of oil and wires» [3]. However, Keiji notices that he cannot use his achievements and experience when distracted by emotions. This means that the more efficient a person wants to become within the mechanized social structure the less sensitive he or she has to be to external factors. It seems that the writer advocates that society as a whole benefits if each member intendedly converses into an entity with explicit limits of freedom and assigned actions.

Despite the fact that science improves the odds of people's survival, the state-of-the-art warfare equipment does not guarantee their victory. The adopted SF conventions help to investigate the ability of technology to sustain the human civilization, once concerned about comfort and development and now threatened by starvation and destruction: «Countries that lacked the means to defend themselves watched as the encroaching desert devoured their land. Developed nations had generally been able to stop the Mimic advance at the coastline, but much of the produce they had taken for granted disappeared from markets and store shelves per night» [3]. As the story illustrates, even though the engineers develop mechanized armors to strengthen the soldiers and protect them from lethal nanobots, Rita Vrataski has to substitute advanced rocket launchers and pile drivers by a simple battle-axe that employs inertia to cut through the Mimics' exoskeletons. Apparently, the writer challenges the ultimate efficiency of technology by highlighting the superiority of human innate abilities and acquired expertise.

Conclusions. In science fiction novum is a means to reveal who we are now and what we may become in the future if we adhere to the existing tendencies in politics, economics, science or culture and do not alter our approaches to environment and society. In «All You Need Is Kill» Sakurazaka constructs a fictional world resembling our real one and introduces the depiction of alien invaders to focus on social and ecological aspects of scientific progress. The novel evokes anxiety about the decline of human mechanized civilization and suggests the importance of simplicity and naturalness for survival. Since humans cannot outmatch extraterrestrial weaponry, they can exploit their indigeneity to their advantage. Refusal to regard everything from the point of view of ultimate utility is a necessary condition for the future survival of humanity. Another concern that runs through the novel as a whole is about the uncontrollable planetary change by means of technology. It becomes reinforced by fear of advanced biological warfare, which reaches the ultimate level of altering the biosphere when indigenous species turn into something completely hostile to natural life. By setting the story in the near future where science and technology threaten the life of the planet and at the same time provide humans the means for survival, the novel manifests the society's desire for progress and fear of its consequences. We hope that our 
analysis may contribute to studying science fiction conventions. Future work may entail further investigation of similarities and differences between the novel and its movie adaptation.

\section{References}

1. Burton J. The Philosophy of Science Fiction : Henri Bergson and the Fabulations of Philip K. Dick / J. Burton. - London ; New York : Bloomsbury, 2015. - 244 p.

2. Roberts A. The History of Science Fiction / A. Roberts. - Houndmills ; New York : Palgrave Macmillan, 2006. - 368 p.

3. Sakurazaka H. All you need is kill [Electronic resource]. H. Sakurazaka ; Translated by Alexander O. Smith. - San Francisco: Viz Media, 2011. - Mode of access : https://epdf.tips/all-you-need-is-kill5090166499d46745f39d89d25a9da47719931.html

4. Science Fiction and Speculative Fiction : Challenging Genres / ed. by P. L. Thomas. - Rotterdam ; Boston ; Taipei : Sense Publishers, 2013. - 220 p.

5. Volk T. What is death ? : A scientist looks at the cycle of life / T. Volk. - New York : Nevraumont Publishing Company, 2002. - 255 p.

Submitted April $16^{\text {th }}, 2019$.

\section{М. О. Федосова}

\section{РЕЦЕПТ ВИЖИВАННЯ: НАУКОВО-ФАНТАСТИЧНИЙ РОМАН ХІРОШІ САКУРАДЗАКИ «ВСЕ, ЩО ТОБІ ПОТРІБНО, - ЦЕ ВБИВАТИ»}

У статті проаналізовано роман Хіроші Сакурадзаки «Все, щзо тобі потрібно, ие вбивати» $i$ показано, як наукова фантастика ідентифікує колективні тривоги й вивчає тендениії розвитку суспільства через створення когнітивного дисонансу за допомогою правдоподібної новачії (поvит), щуо виражається у формі незвичайних технологій та інопланетних істот, включених в зображення звичної дійсності, $i$ постає засобом дослідження сталих ідей чи упереджень. В аналізованому романі згубний вплив людства на довкілля є стрижневою темою, навколо якої обертаються інші, зокрема тема механізації суспільства, впливу смерті на спільноту, а також неконтрольованих планетарних змін, спричинених технологіями. Механізація розглядається не лише як схильність людини зводити інших осіб чи істот до ролі засобів забезпечення власного існування, а й, за Бергсоном, як спосіб дискретного сприйняття всесвіту без осягнення його неперервності. Роман викриває філософію індустріалізованого суспільства і застерігає від глобальної екологічної катастрофи. Механізачія загрожує сучасній культурі й підриває основи моралі, оскільки дозволяє домінувати наукоцентричному мисленню, що применшуе статус життя в його цілісності, позбавляе істот, щуо вважаються нижчими, справедливості й права автономного існування. У романі засуджується нездатність суспільства надавати перевагу живим істотам над речами навіть перед неминучою загрозою руйнування планети. Зустріч героя з власною смертю приводить до усвідомлення того, щзо людина постійно перебуває між потребою жити та неминучістю загибелі, тому має зробити вибір на користь вищого добра, а не простого вижсивання. Смерть іншого посилює наявні риси характеру, які, якщьо вони позитивні, можуть надихати на покращення суспільства. У часовій петлі постійна зміна життя і смерті дозволяє протагоністу Кеідзі Кірії впоратися зі страхом, зміцнити відчуття відповідальності й самоповаги. Суб'єктивний час у романі завжди лінійний, оскільки герой пам'ятає всі минулі події $i$ його ментальність не повертається до попереднього стану. Загибель подруги Рити Вратаскі навчає Кеідзі, щฺо сутність людського життя полягає не лише 
у знищенні ворогів, але й у здійсненні добрих вчинків, навіть якщя ніхто крім нього їх не оцінить. У романі розмитість межі між природними та науково вдосконаленими істотами репрезентує трансформацію людства під впливом технологій, а в образі інопланетних загарбників втілюється найвищий рівень механізаиї суспільства. Письменник бере під сумнів граничну ефективність технологій, надаючи перевагу природженим здібностям людини й набутому досвіду.

Ключові слова: часова петля, тераформування, екологічний розрив, технологія, механізація.

\section{УДК 821.112.2.09}

\section{Г. М. Шевців}

\section{«ПОЕЗІЯ І ПРАВДА» Й.-В. ГЕТЕ ПРО БІБЛІЮ ЯК ДЖЕРЕЛО ДУХОВНОГО ОБРАЗУ АВТОБІОГРАФА}

Статтю присвячено розгляду впливу Біблї̈ на формування особистості Гете. Проаналізовано спогади Гете про його дитяче та юначьке ставлення до Біблії та релігіі. На основі тексту «Поезії і правди» простежено формування релігійних переконань ї̈ автора. Узагальнено різні точки зору українських, російських і німечьких літературознавиів на релігійні погляди зрілого Гете.

Ключові слова: автобіографія, автор, Біблія, сповідь, спогад, епізод, переконання, релігія, християнство.

DOI 10.34079/2226-3055-2019-12-20-157-162

Постановка проблеми. Для розуміння творчості Гете надзвичайно важливим $€$ вивчення його релігійних переконань, які наклали свій відбиток на моральні й світоглядні позиції та художній світ літературної спадщини письменника. Пошуки справжньої, на думку Гете, релігії провели його через особистий досвід, спостереження, розмови, заняття природничими науками від раннього захоплення пієтизмом до зрілого пантеїзму - вчення про те, що Бог у всесвіті та невіддільний від нього.

Аналіз останніх досліджень і публікацій, в яких започатковано розв'язання даної проблеми. При достатньо вивченому на сьогодні світогляді Гете серед дослідників його наукової та творчої спадщини не існує одностайності стосовно проблеми «Гете та релігія». Розвідки науковців дуже різняться, інколи аж до протилежності $[1 ; 2 ; 5 ; 8]$. У центр дослідження, як правило, виводиться драма «Фауст» та окремі твори Гете («Одно і все», «Страждання молодого Вертера», «Споріднені душі», «Егмонт», «Гец фон Берліхінген», «Ксенії IX», «Венеціанські епіграми», «Західно-східний диван»), у яких чітко проглядаються старозавітні ремінісценції та зацікавлення автора східними релігіями. Для розуміння поглядів Гете на християнство та формування його пантеїстичних позицій багатим джерелом інформації стає «Поезія і правда». Ця автобіографія не лише подає фактичний матеріал, але й демонструє його авторське переосмислення, чим пояснює багато дискусійних питань. Саме тому метою нашого дослідження є аналіз окремих уривків автобіографії Гете, які демонструють ставлення письменника до Біблії, з якою він «власне кажучи 